Article

\title{
Energy Performance Evaluation of a Desiccant Air Handling System to Maximize Solar Thermal Energy Use in a Hot and Humid Climate
}

\author{
Makiko Ukai ${ }^{1, *}$, Masaya Okumiya ${ }^{1}$ and Hideki Tanaka ${ }^{2}$ \\ 1 Graduate School of Environmental Studies, Nagoya University, Nagoya 464-8603, Japan; \\ okumiya@davinci.nuac.nagoya-u.ac.jp \\ 2 Campus Planning \& Environment Management Office, Nagoya University, Nagoya 464-8603, Japan; \\ tanaka@nagoya-u.jp \\ * Correspondence: ukai@nuac.nagoya-u.ac.jp
}

Received: 3 February 2020; Accepted: 1 March 2020; Published: 3 March 2020

\begin{abstract}
A desiccant air handling unit is one of the major types of dehumidification handling systems and requires hot water or hot air to regenerate sorption materials. If solar thermal energy is used as the heat source for regeneration, in general, a backup electrical heater, backup boiler, or combined heat and power (CHP) is installed in order to maintain a stable hot water supply. In this study, effective control is proposed for a desiccant air handling system that uses solar thermal energy (flexible control), and its energy performance is compared to that of a traditional control (the fixed control) through a system simulation. The diurnal behavior shows that the system with a fixed control without a backup boiler cannot process the latent load properly (28 GJ of unprocessed latent load for July and August). On the other hand, the system with a flexible control without a backup boiler is able to process required latent heat load. Based on the fact that the fixed control needs a backup boiler to process the latent load, the system with a fixed control with a backup boiler is considered for the energy performance comparison. The simulation results show that the primary energy-based coefficient of performance (hereafter, COP) of the system with a flexible control without a backup boiler reaches 1.56. On the other hand, the primary energy-based COP of the system with a fixed control with a backup boiler reaches only 1.43. This proves that the flexible control contributes to the higher energy performance of the system and maximizes the use of solar thermal energy more than the fixed control.
\end{abstract}

Keywords: desiccant air handling unit; performance evaluation; flexible control

\section{Introduction}

Today, the concept of a net zero energy building (ZEB) is widely recognized, and the popularization and promotion of ZEBs is desired [1-3]. The indoor thermal load through the outer wall and windows has been decreasing due to the higher performance of insulation [4]. Furthermore, the indoor sensible heat load has become very small now thanks to light emitting diode (LED) lighting and the better energy efficiency of computers. On the other hand, the metabolic rates of humans do not change very much. Therefore, although the constitution of the thermal loads of buildings has changed, the latent load from humans still seems to be relatively large. In addition, global warming is a worldwide issue, thereby increasing the temperature and humidity in some areas of Japan (for example, Nagoya area) [5]. This results in a larger fresh air load. Thus, dehumidification in Japan is important for indoor environments.

One of the major dehumidification systems involves desiccant air handling units, in which a solid adsorbent absorbs water content in the air. In order to regenerate the adsorbent, hot water or hot air is 
necessary. Therefore, solar thermal energy and desiccant air handling units are a good combination. When solar energy is utilized, a backup electric heat heater, gas boiler, or combined heat and power (CHP) is installed due to the fluctuation and instability of solar energy. According to this paper [6], almost all of the reviewed systems have an auxiliary heater or boiler for solar water or an air collector. Angrisani [7] conducted a dynamic simulation on solar-assisted desiccant-based air handling units with backup boilers in two Italian cities. Angrisani's results showed maximum primary energy saving of about $10 \%$ and $20 \%$ with flat plate and evacuated tube collectors, respectively. According to Fong [8], a solar desiccant cooling system with a backup gas heater achieves $35.2 \%$ savings of year-round primary energy consumption compared to conventional air-conditioning systems.

Comino [9] conducted an experimental energy performance assessment of a solar desiccant cooling system in Southern European Climates. Comino's desiccant air handling unit only had a solar thermal collector for the regenerating coil, so there were no backup heaters. However, the authors pointed out that it is not possible to achieve a humidity ratio point of $8 \mathrm{~g} / \mathrm{kg}$ when the solar heat gain is low. The authors proposed to install thermal energy storage for solar thermal collectors to reduce the unprocessed latent load, but this possibility was not researched. Zied [10] conducted a numerical simulation without an auxiliary heater but did not consider a situation where solar thermal energy is not enough for regeneration. Enteria [11] conducted first and second law analyses of solar desiccant air conditioning over one day. The heater operated overnight to store thermal energy to support the early hours of its operation. The solar fraction was around 75\% thermal energy. There is no research on desiccant air handling units without backup heaters, boilers, or CHP. For the desiccant material of the aforementioned papers, silica gel was adopted.

In this study, a polymer sorbent was employed as a desiccant material. This material can achieve greater dehumidification than silica gel when dehumidifying high-relative-humidity air with low-temperature regeneration air [12].

This study proposes a desiccant (polymer sorbent) air-handling unit with solar thermal energy without using a backup heater or boiler and evaluates the energy performance of the desiccant air handling system through simulation.

In order to avoid using a backup heat source, the proposed solution's equipment uses variable control that considers the hot water temperature from solar thermal system and the air state entering the dehumidification material. This new control will contribute to the effective use of solar thermal energy.

The purpose of this study is to

- Analyze the air state in a desiccant air handling unit with the traditional control and the proposed control;

- Evaluate the energy performance with the new control and compare it with the energy performance with a normal control.

\section{Targeted Building and System}

This section provides details on the targeted building, the desiccant air handling unit, and the heat source systems.

\subsection{Targeted Building}

The targeted building is an office building located in Tokyo, Japan. It has five stories; the air-conditioning area of a typical floor is $983 \mathrm{~m}^{2}$, as shown in Figure 1 (the total floor area is about $1106 \mathrm{~m}^{2}$ ). The opening ratio (the windowed area divided by the wall area) of the building is $41.5 \%$. This building was designed with some energy saving methods, including eaves, high insulated walls and roofs, and LED lighting. The U-value of the outer wall is $0.6 \mathrm{~W} / \mathrm{m}^{2} \mathrm{~K}$, and low-e double glazed windows are installed, with heat transmission resistance of $0.385 \mathrm{~m}^{2} \mathrm{~K} / \mathrm{W}$. The room's set temperature is $28^{\circ} \mathrm{C}$, and the relative humidity is $40 \%$ during the cooling period, according to the comfort zone described by Kato [13] and the "Cool Biz" [14] campaign, where appropriate room conditions and 
clothes were proposed. The load calculation is conducted with Micro HASP/TES [15], which gives periodic stationary calculations for one year. Standard meteorological phenomena data are used for the thermal load calculation. In this paper, July and August, which are hot and humid seasons, are used for the simulation. Figure 2 shows the load ratio of the building for July and August. Almost half of the thermal load is latent heat load.

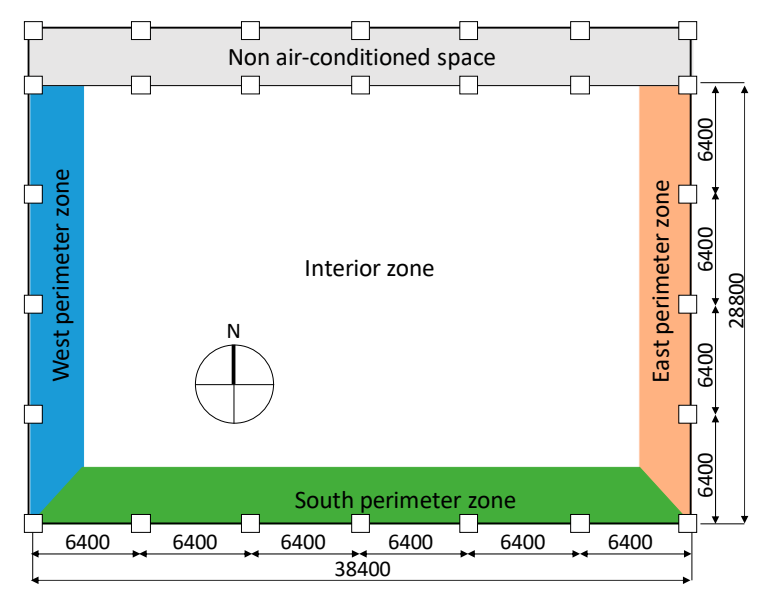

Figure 1. Typical floor plan.

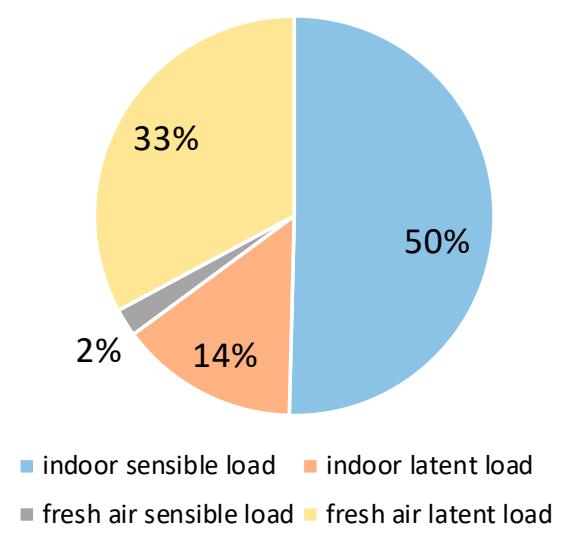

Figure 2. Thermal load of the building for July and August.

\subsection{Desiccant Air Handling Unit}

Figure 3 shows the configuration of the desiccant air handling unit (DAHU), the sensible air handling unit, the solar thermal system and the heat source system. For DAHU, fresh outdoor air is supplied to the desiccant system directly. The system in this study is composed of a pre-cooling coil, a dehumidification wheel, a sensible heat exchanger, an after-cooling coil, and a regenerating coil, as shown in Figure 3. Fresh air (1; the number in brackets is correlated to the number in Figure 3) is provided to the pre-cooling coil to be precooled and dehumidified (2), which then passes the dehumidification wheel (3), the sensible heat exchanger (with return air) (4), and the after-cooling coil (5). The return air (RA) (6) passes the sensible heat exchanger (7) and is then heated by the regenerating coil (8). The high temperature air desorbs moisture from the polymeric adsorbents and is finally exhausted (9).

The desiccant air handling unit processes the entire fresh outdoor load (sensible and latent heat), all of the indoor latent heat, and part of indoor sensible heat. The indoor sensible heat processed by DAHU is derived from lighting and appliances. Each floor has an air handling unit for the remaining indoor sensible heat load, which is called a sensible air handling unit (SAHU).

For chilled water, air source heat pumps are installed to supply a pre-cooling and after-cooling coil in DAHU and a cooling coil for SAHU. 
For the regeneration of the sorbents, a solar thermal system is installed. Heat collected through the evacuated tube type solar thermal collector is first stored in the solar thermal tank, and then hot water from the tank is supplied to the regenerating coil in DAHU when the temperature reaches its set point.

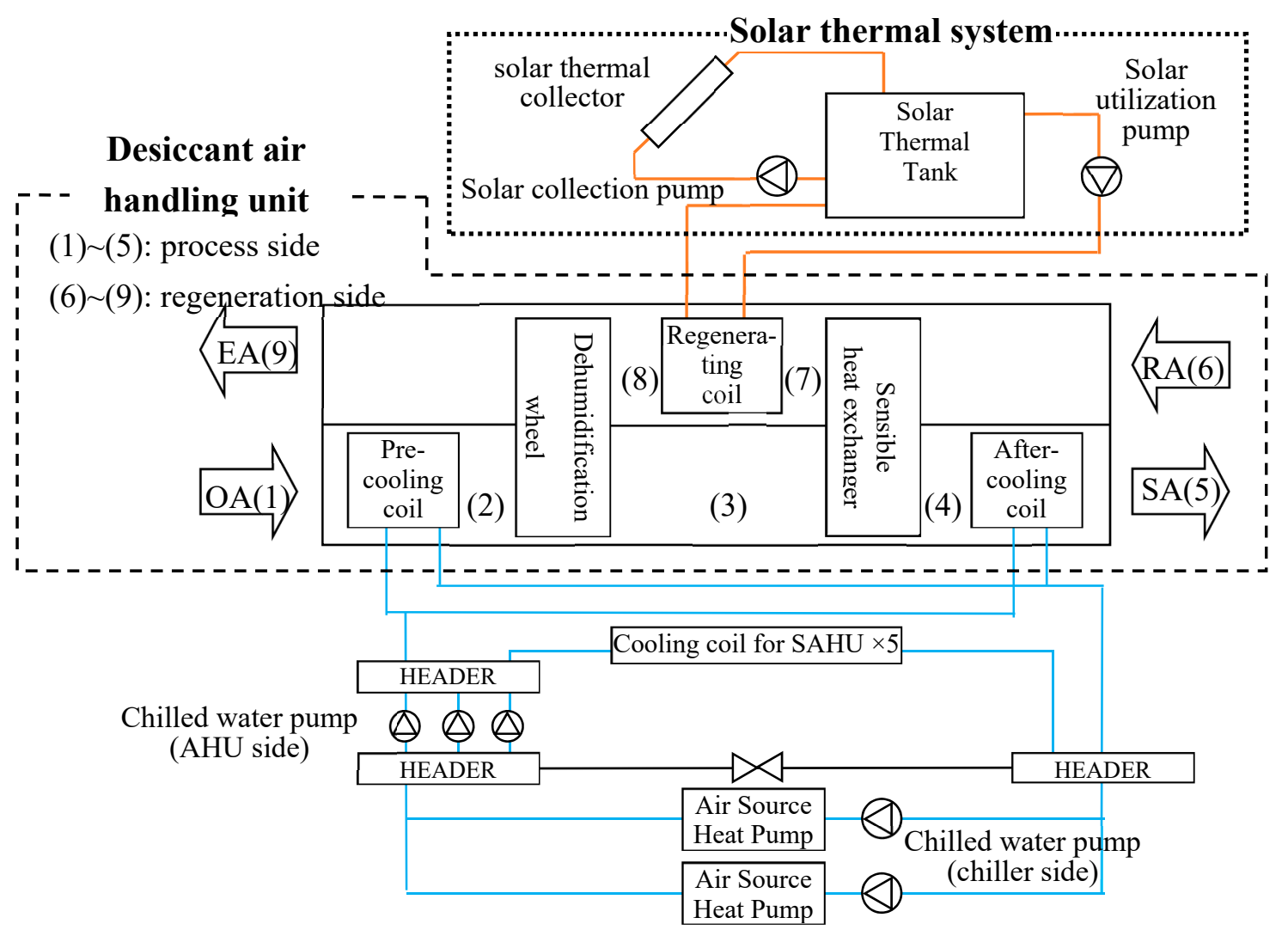

Figure 3. Diagram of the air handling unit and heat source system.

\section{Design of the DAHU and Heat Source for Controls}

This section provides the details of the traditional control, called a "fixed control", and the newly proposed control, called a "flexible control", as well as the design process for the DAHU and heat source.

\subsection{Fixed Control (Traditional Control)}

Figure 4 shows the diagram of the traditional fixed control. The ordinary fixed control controls the air temperature by leaving the pre-cooling coil at a fixed temperature (for example, $19^{\circ} \mathrm{C}$ ), and the relative humidity is $95 \%$. Therefore, the dehumidification amount handled by the dehumidification wheel and the regeneration coil demand do not fluctuate very much. The reason why fixed control is traditionally used is that a fixed control provides stable pre-cooling, a stable regenerating coil, and stable after-cooling demand, which stabilizes the whole system's balance. 


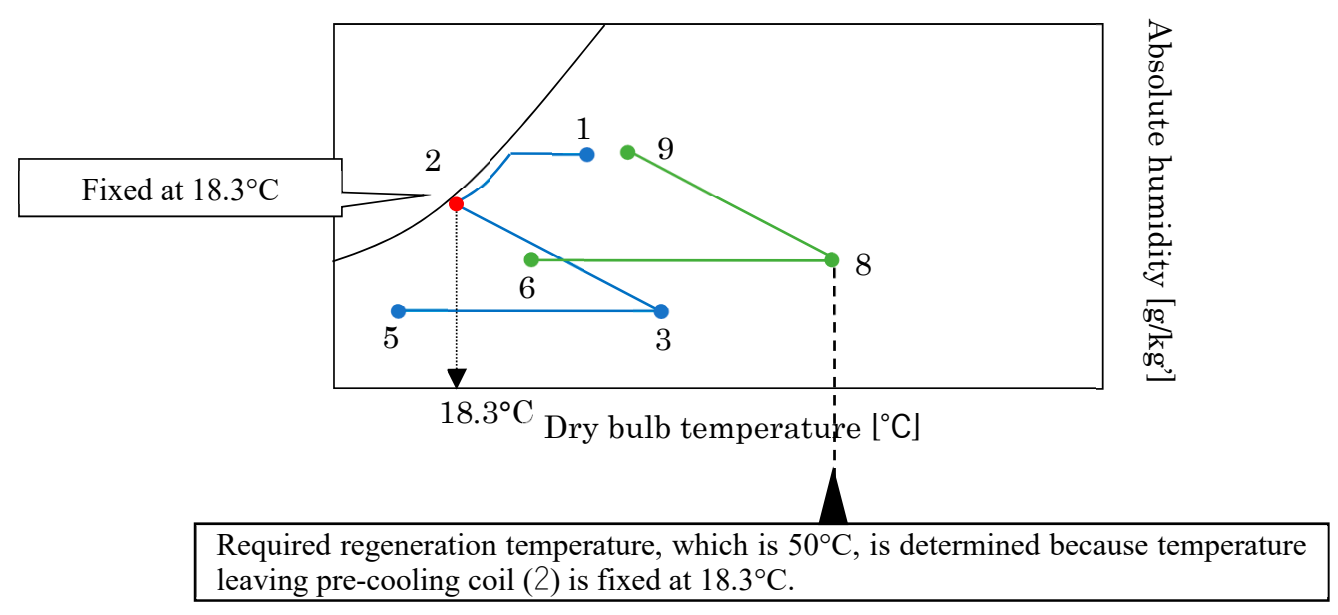

Figure 4. Diagram of the fixed control.

According to Stephan [12], a higher relative humidity in the air entering the dehumidification wheel at the process side achieves greater dehumidification with a polymer sorbent, even if the regeneration temperature is low. Thus, in a fixed control, the air state leaving the pre-cooling coil is set at $18.3^{\circ} \mathrm{C}$, according to the preliminary simulation of the DAHU itself, without a heat source system. At this point, the value of thermal energy efficiency, which is given by the processed air amount divided by the total coil demand (including the pre-cooling coil, regenerating coil, and after cooling coil), is the best. Depending on the load distribution and specification of the DAHU (shown in Table 1), the required total cooling coil demand for the pre-cooling and after-cooling coil and the hot water demand for the regenerating coil of the DAHU are $355 \mathrm{~kW}$ and $124 \mathrm{~kW}$, respectively. For chilled water, in addition to the cooling demand of the DAHU, the coil demands of the SAHU $(24.8 \mathrm{~kW} /$ floor and $33.5 \mathrm{~kW} /$ floor on a typical floor and the top floor, respectively) are considered. In total, the chilled water demand is $488.2 \mathrm{~kW}$. For the solar collector, the average collection factor is set at $50 \%$; therefore, the area of the collector is set at $242 \mathrm{~m}^{2}$. Table 2 shows the specifications of each system. The specifications of the components with fixed controls are shown in Table 2.

Table 1. Design conditions for the desiccant air handling unit with fixed controls.

\begin{tabular}{cccc}
\hline $\begin{array}{c}\text { Air state No. as Shown } \\
\text { in Figure } 3\end{array}$ & $\begin{array}{c}\text { Temperature } \\
{ }^{\circ} \mathbf{C}\end{array}$ & $\begin{array}{c}\text { Humidity } \\
\mathbf{g} / \mathbf{k g}^{\prime}\end{array}$ & Assumption and so on \\
\hline 1 & 32.5 & 19.9 & Outdoor condition given by load calculation \\
\hline 2 & 18.3 & 12.3 & Relative humidity is $95 \%$ \\
\hline 3 & 33.3 & 6.5 & Relative humidity efficiency is $90 \%$ \\
\hline 4 & 29.1 & 6.5 & Efficiency is $80 \%$ \\
\hline 5 & 15.4 & 6.5 & Supply air condition at peak time is $15.4^{\circ} \mathrm{C}$ \\
\hline 6 & 28.0 & 9.4 & Room air condition $\left(28^{\circ} \mathrm{C}, 40 \%\right)$ \\
\hline 7 & 31.8 & 9.4 & Sensible heat exchange efficiency is $80 \%$ \\
\hline 8 & 50.0 & 9.4 & Absolute humidity is the same as return air \\
\hline
\end{tabular}

1 In this assumption, the capacity of dehumidification wheel and heat transfer from regeneration side to process side due to rotation is not considered. 
Table 2. Specifications of the system.

\begin{tabular}{|c|c|c|c|}
\hline & Abbreviations & Rated Specifications & Number \\
\hline Air-source HP & ASHP & $\begin{array}{l}\text { Cooling capacity: } 265 \mathrm{~kW} \text {; electricity } \\
\text { consumption: } 66 \mathrm{~kW}\end{array}$ & 2 \\
\hline $\begin{array}{l}\text { Evacuated tube-type } \\
\text { solar collector }\end{array}$ & SOL & $242 \mathrm{~m}^{2}$, tilt angle: 15 , facing to the south & \\
\hline $\begin{array}{l}\text { Thermal storage tank for } \\
\text { the solar thermal system }\end{array}$ & TANK $_{\mathrm{SOL}}$ & $10 \mathrm{~m}^{3}$ & 1 \\
\hline $\begin{array}{l}\text { Desiccant air handling } \\
\text { unit }\end{array}$ & DAHU & $\begin{array}{c}\text { Desiccant material: polymer sorbent } \\
\text { Supplied air volume: } 22,115 \mathrm{~m}^{3} / \mathrm{h} \text {; exhaust air } \\
\text { volume: } 19,904 \mathrm{~m}^{3} / \mathrm{h} \\
\text { For the fixed control: } \\
\text { Pre-cooling coil: } 253.0 \mathrm{~kW} \text {; after-cooling coil: } \\
102 \mathrm{~kW} \text {; regenerating coil: } 123.0 \mathrm{~kW} \\
\text { For the flexible control: } \\
\text { Pre-cooling coil: } 361 \mathrm{~kW} \text {; after-cooling coil: } \\
32 \mathrm{~kW} \text {; regenerating coil: } 123 \mathrm{~kW} \text { (the } \\
\text { regenerating coil and after cooling coil } \\
\text { demand is based on the fixed control) }\end{array}$ & 1 \\
\hline \multirow{2}{*}{$\begin{array}{l}\text { Sensible air handling } \\
\text { unit }\end{array}$} & \multirow[t]{2}{*}{ SAHU } & $\begin{array}{l}\text { Supply/ Return air: } 6612 \mathrm{~m}^{3} / \mathrm{h} \text {; cooling coil: } \\
25 \mathrm{~kW} \text { (on a typical floor) }\end{array}$ & 4 \\
\hline & & $\begin{array}{l}\text { Supply/ Return air: } 8941 \mathrm{~m}^{3} / \mathrm{h} \text {; cooling coil: } \\
33.5 \mathrm{~kW} \text { (on the top floor) }\end{array}$ & 1 \\
\hline Chilled water pump & $\mathrm{PUMP}_{\text {chiller }}$ & $\begin{array}{l}\text { Flow rate: } 7601 / \mathrm{min} \\
\text { Head: } 147 \mathrm{kPa}\end{array}$ & 2 \\
\hline $\begin{array}{l}\text { Chilled water pump } \\
\text { (AHU side) }\end{array}$ & $\mathrm{PUMP}_{\mathrm{AHU}}$ & $\begin{array}{l}\text { Flow rate: } 4741 / \mathrm{min} \\
\text { Head: } 441 \mathrm{kPa}\end{array}$ & 3 \\
\hline Solar collection pump & PUMPs & $\begin{array}{l}\text { Flow rate: } 2401 / \mathrm{min} \\
\text { Head: } 348 \mathrm{kPa}\end{array}$ & 1 \\
\hline Solar utilization pump & PUMPsu & $\begin{array}{l}\text { Flow rate: } 2401 / \mathrm{min} \\
\text { Head: } 258 \mathrm{kPa}\end{array}$ & 1 \\
\hline
\end{tabular}

The capacity of the chiller is determined to cover the chilled water demand for both the fixed and flexible control.

\subsection{Flexible Control}

Figure 5 shows the flexible control proposed in this study. The flexible control controls the conditioned air leaving the pre-cooling coil with the absolute humidity of the supply air and the hot water temperature entering the regenerating coil. When the hot water temperature is not sufficiently hot, the temperature leaving the pre-cooling coil decreases, and the dehumidification amount at the pre-cooling coil increases. However, when the hot water temperature is very hot, the temperature leaving the pre-cooling coil increases, and the dehumidification amount at the pre-cooling coil decreases, which results in a larger dehumidification amount at the dehumidification wheel.

The flow of the system is shown below:

Step 1: When the temperature in the tank is above the set point, the hot water from the tank is supplied to the regenerating coil.

Step 2: The regeneration temperature (T8) is determined based on the hot water from the tank.

Step 3: Based on the regeneration temperature determined in Step 2, if the absolute humidity (AH3) is higher than the set point of supply for absolute humidity, then the set temperature leaving the pre-cooling coil (T2) decreases, and the absolute humidity leaving the pre-cooling coil (AH2) also decreases at the same time until the absolute humidity (AH3) fulfills the set point of absolute humidity. 

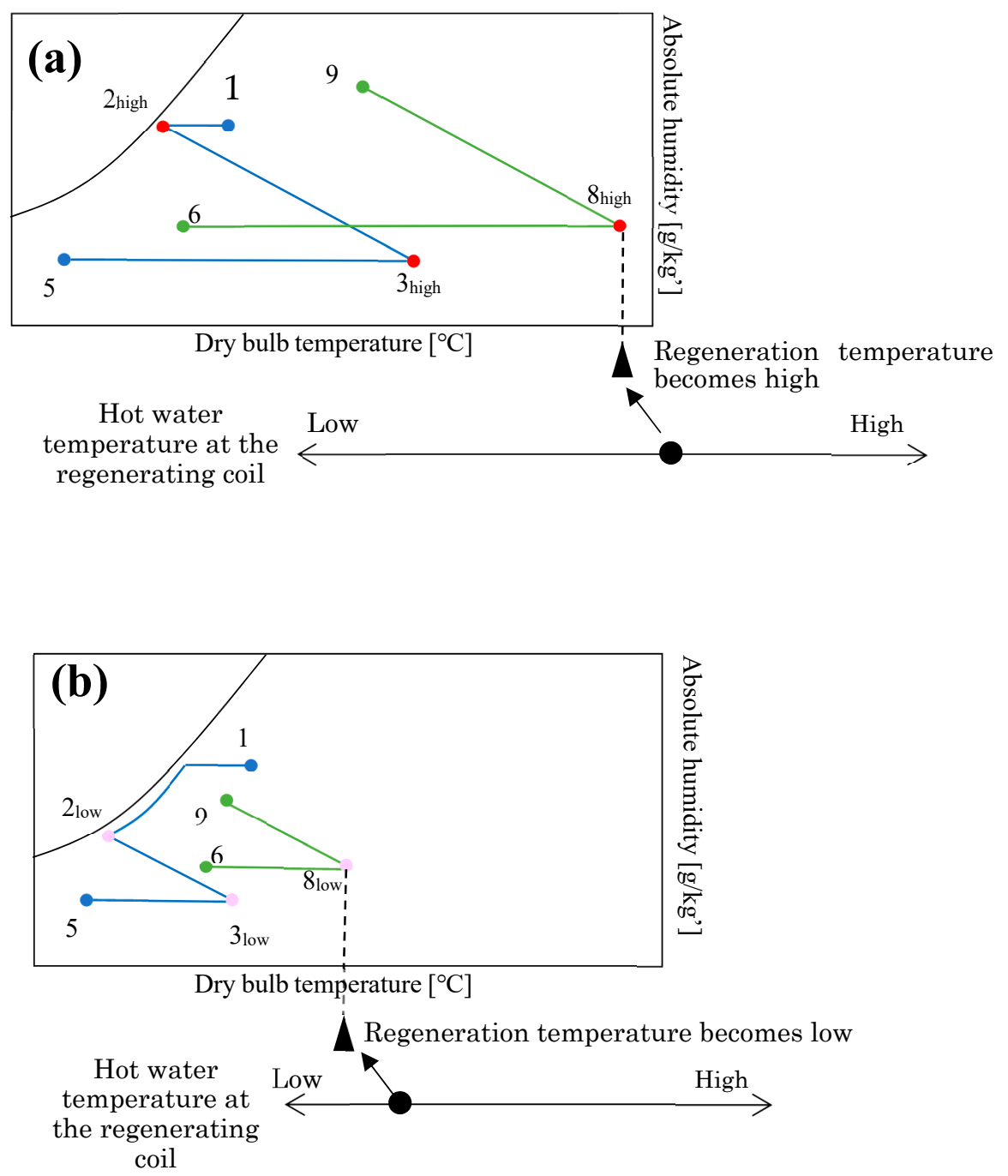

Figure 5. Diagram of the flexible control. (a) Air state in the DAHU when the hot water temperature at the regenerating coil is high; (b) Air state in the DAHU when the hot water temperature at the regenerating coil is low.

In the flexible control, for the design phase, the air state leaving the pre-cooling coil is set at $13{ }^{\circ} \mathrm{C}$, which is sufficient to dehumidify the air without solar thermal energy. The required total pre-cooling cooling coil and after-cooling coil demand for the DAHU is $393 \mathrm{~kW}(361 \mathrm{~kW}+32 \mathrm{~kW}$, respectively). For the chiller, in addition to the pre-cooling and after-cooling coil demands of the DAHU, the coil demand of the SAHU $(24.8 \mathrm{~kW} /$ floor and $33.5 \mathrm{~kW} /$ floor on a typical floor and on the top floor, respectively) is considered. In total, the chilled water demand is $526.6 \mathrm{~kW}$. The same regeneration coil and solar thermal collector with fixed controls were installed. Table 2 shows the specifications of the system with both fixed and flexible controls.

\section{Outline of the Simulation}

The simulation used in this study was done with the LCEM tool $[16,17]$, which was developed under the supervision of the Ministry of Land, Infrastructure, Transport, and Tourism. This is a simulation tool based on Microsoft Excel. 


\subsection{Dehumidification Wheel}

In this tool, factor of dehumidification wheel is coefficient of relative humidity. Coefficient of relative humidity is defined as equation (1). The desiccant material in this study is a polymer sorbent $[18,19]$.

The relative humidity entering the dehumidification wheel of the process also affects the performance of the DAHU. According to the measurement results for the polymer sorbent desiccant air handling unit installed in an office building in Japan (please see appendix Figure A1), when the relative humidity entering the dehumidification wheel is over $80 \%$, the coefficient of relative humidity is constant at around 0.9. Thus, in this study, the value is set to 0.90 .

$$
\eta_{R H}=\frac{R H_{2}-R H_{3}}{R H_{2}-R H_{8}}
$$

\subsection{Coils}

The calculation method is based on the factor of a wetted surface, which is traditionally employed for designing coils in Japan. In this method, the process for calculating the number of coil columns is used inversely to provide the outlet conditions of the air and water. The outlet temperature of the water and its flow rate will be calculated by Equations (2)-(19).

$$
\begin{gathered}
\mathrm{qc}=R O W \times K F \times d t l m \times A F \times W S F \\
\mathrm{KF}=\frac{a_{1}}{\left(\frac{1}{a_{2} \times u f^{a 3}+a_{4}}+\frac{1}{a_{5} \times v w^{a 6}+a_{7}}\right)} \\
\mathrm{WSF}=a_{8} \times S H F^{2}+a_{9} \times S H F+a_{10} \\
\mathrm{dtlm}=\frac{d t 1-d t 2}{\ln \left(\frac{d t 1}{d t 2}\right)} \\
\mathrm{dt} 1=T_{c a i}-T_{c w o} \\
\mathrm{dt} 2=T_{c a o}-T_{c w i} \\
\mathrm{Z}=\frac{\mathrm{dt} 1}{d t 2} \\
\mathrm{DOW} \times \mathrm{KF} \times \mathrm{AF} \times \mathrm{WSF} \\
q c=D \frac{d t 2 \times(\mathrm{Z}-1)}{\ln \mathrm{Z}} \\
\mathrm{qc}=V_{\text {air }} \times \rho_{a i r}\left(H_{c a i}-H_{c a o}\right) \\
\mathrm{E}=\frac{Q_{w}}{D \times d t 2} \\
\mathrm{E} \times \ln \mathrm{Z}=\mathrm{Z}-1 .
\end{gathered}
$$

Equation (13) is a transcendental equation. Therefore, the approximate positive solution from Equations (14) to (16) are used:

$$
\begin{gathered}
\text { If } 0<\mathrm{E}<0.1 \quad \mathrm{Z}=\exp \left(\frac{-1}{E}\right) \\
\text { If } 0.1 \leq \mathrm{E}<1
\end{gathered}
$$

If $1 \leq \mathrm{E}<100$

$$
\mathrm{Z}=\frac{-0.32473+0.320074 \times E+1.27473 \times E^{2}+0.0371635 \times E^{3}}{1+0.304950 \times E+0.00456563 \times E^{2}}
$$




$$
\begin{gathered}
T_{c w o}=T_{c a i}-Z \times d t 2 \quad(\text { for cooling }) \\
T_{c w o}=T_{c a i}+Z \times d t 2 \quad(\text { for heating }) \\
W_{c o i l}=\frac{60 \times q c}{C_{w} \times\left(T_{c w i}-T_{c w o}\right)} .
\end{gathered}
$$

Based on the flow rate calculated by Equation (19), the flow rate in the coils is provided again; then, the KF from Equation (3) continues to be calculated until reaching convergence.

\subsection{Sensible Heat Exchanger}

The sensible heat exchanger is modelled with a face velocity and air volume ratio sufficient to provide efficiency, as shown in Equations (20) and (21); $a$ to $l$ are the default values.

$$
\begin{aligned}
& S E C_{\text {pro }}=(b r+c) U_{p r o}^{2}+(\mathrm{dr}+\mathrm{e}) U_{\text {pro }}+(f r+g) \\
& S E C_{r e}=(h / r+i) U_{r e}^{2}+(\mathrm{j} / \mathrm{r}+\mathrm{k}) U_{r e}+(l / r+m)
\end{aligned}
$$

\subsection{Solar Collector}

The solar thermal collector object is modelled by Equations (22)-(24) [20]:

$$
\begin{gathered}
\eta_{c o l}=\frac{\mathrm{n} \Delta T}{J}+o \\
\Delta \mathrm{T}=\frac{T_{c o l-i n}+T_{c o l-o u t}}{2}-T_{a m b} \\
Q_{c o l}=\eta_{c o l} J A=\frac{c \rho W_{c o l}\left(T_{c o l-o u t}-T_{c o l-i n}\right)}{3600} .
\end{gathered}
$$

Coefficients $n$ and $o$ are -0.473 and 0.561, respectively, for the specified values of evacuated tube type collectors. The collectors are divided into two modules. The area of each module is $121 \mathrm{~m}^{2}$, and the modules are arrayed in parallel. The collectors face the south, and their tilt angle is $15^{\circ}$.

For flat type collectors, $n$ and $o$ are -0.393 and 0.840 , respectively.

The collection pump operates when the temperature difference between the inlet and outlet temperature of the collectors is larger than $1.0^{\circ} \mathrm{C}$, and the temperature in the tank is lower than $90^{\circ} \mathrm{C}$.

\subsection{Thermal Storage Tank}

The characteristics of the thermal storage tank are assumed to be completely mixed. The thermal storage tank is modelled by Equation (25).

$$
c \rho V_{t s} \frac{d T_{t s}}{d t}=K_{t s} S_{t s}\left(T_{a m b}-T_{t s}\right)+Q_{c o l}+Q_{s u p} .
$$

When the temperature in the tank is higher than $55^{\circ} \mathrm{C}$, hot water from the tank is supplied to the regenerating coil in the DAHU in both the fixed and flexible controls.

\subsection{Boundary Conditions}

The same outdoor conditions, including temperature, humidity, and solar radiation, used for the load calculations are provided. The supply and return air volumes are stable at 22,155 $\mathrm{m}^{3} / \mathrm{h}$ and $19,904 \mathrm{~m}^{3} / \mathrm{h}$, respectively. Based on the load calculations, the supply set point for the desiccant air handling unit is given as the boundary condition. 


\subsection{Simulation Cases}

In this study, we used four cases, as shown in Table 3. For the fixed control, an evacuated tube type of solar thermal collector is installed. For the flexible control, a flat plate collector is also considered, based on the report in [21]. In 2017, flat plate collectors were ranked second place in terms of their total installed capacity in operation according to collector type, but the report says that the share of flat plate collectors increased by $10 \%$ in 2017. In both fixed and flexible control systems, chilled water at $7{ }^{\circ} \mathrm{C}$ is supplied to each coil. Furthermore, for the fixed control, a system with a backup boiler is considered.

Table 3. Outline of simulation cases.

\begin{tabular}{cccc}
\hline Case Name & Control & Solar Collector Type & Backup Boiler \\
\hline Case FI-ET & Fixed control & Evacuated tube type & None \\
\hline Case FL-ET & Flexible control & Evacuated tube type & None \\
Case FL-FP & & Flat plate type & None \\
\hline Case FI-ET with backup boiler & Fixed control & Evacuated tube type & $\sqrt{ }$ \\
\hline
\end{tabular}

\section{Simulation Results and Evaluation}

The simulation is conducted for July and August. First, the diurnal behavior is verified to determine the air state in the DAHU and the condition of solar thermal utilization. Then, energy performance is analyzed over two months

\subsection{Diurnal Behavior}

Figures 6 and 7 show the diurnal behavior in the DAHU on the representative day, 11th August. In both figures, each number corresponds to the numbers in Figure 3.

For the fixed control, as shown in Figure 6, the temperature leaving the pre-cooling coil (T2) is stable at $18.8^{\circ} \mathrm{C}$, and the required regeneration temperature (T8) is $50^{\circ} \mathrm{C}$. On the other hand, for the flexible control shown in Figure 7a, the temperature leaving the pre-cooling coil (T2) varies between 14 and $20^{\circ} \mathrm{C}$, and the required regeneration temperature (T8) varies from 54 to $56^{\circ} \mathrm{C}$. During the calculation period, the maximum regeneration temperature was $68.2^{\circ} \mathrm{C}$.

The absolute humidity supply (AH5) (as shown in Figure 6b) for fixed control does not fulfill the set point at $6.78 \mathrm{~g} / \mathrm{kg}^{\prime}$ at 10:00, 12:00, 15:00, and 17:00. This is because the temperature in the tank is not high enough, and hot water from the tank is not provided to regenerate the coil, as shown in Figure $6 \mathrm{~d}$.

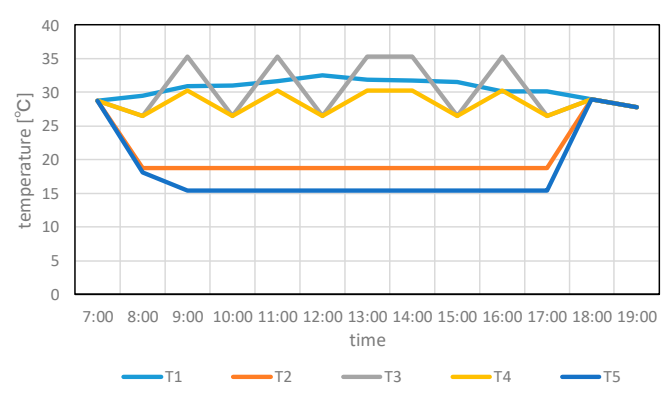

(a) Temperature of the processed side

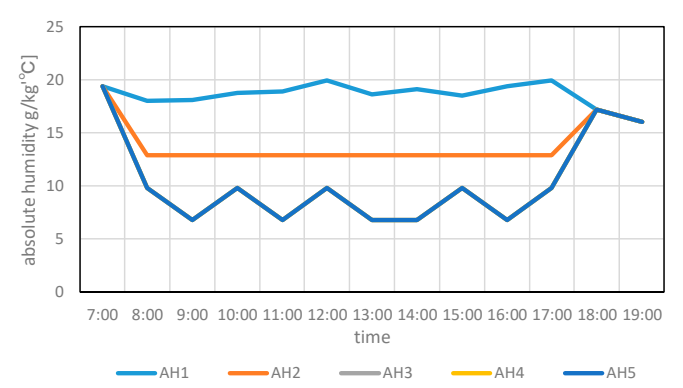

(b) Absolute humidity of the processed side

Figure 6. Cont. 


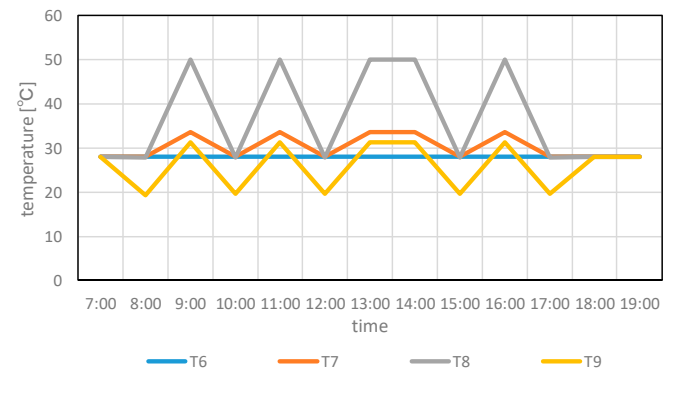

(c) Temperature of the regeneration side

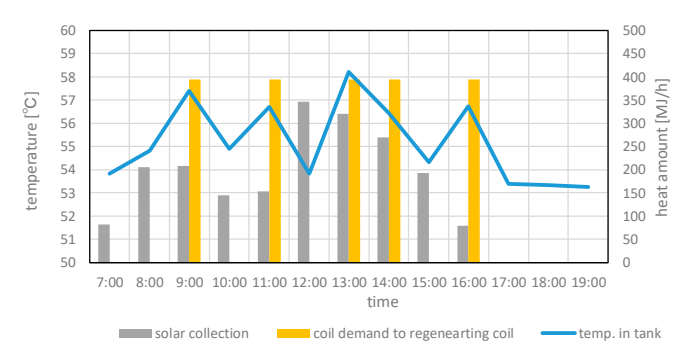

(d) Solar collection, coil demands of regeneration coil, and temperature in the tank

Figure 6. Diurnal behavior for the fixed control with an evacuated tube type collector.

On the other hand, the flexible control shown in Figure $7 \mathrm{~b}$ fulfills the set point of the absolute humidity supply (AH5), even when the solar energy is not provided to the regenerating coil (for example, at 10:00, 11:00, 13:00, 15:00, and 17:00). At these times, the required chilled water demand becomes large, and absolute humidity leaving the pre-cooling coil (AH2) is low (below around $9 \mathrm{~g} / \mathrm{kg}^{\prime}$ ) in order to compensate for the lack of hot water.

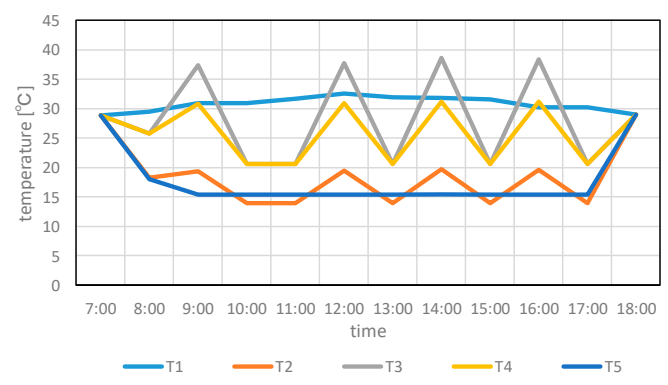

(a) Temperature of the processed side

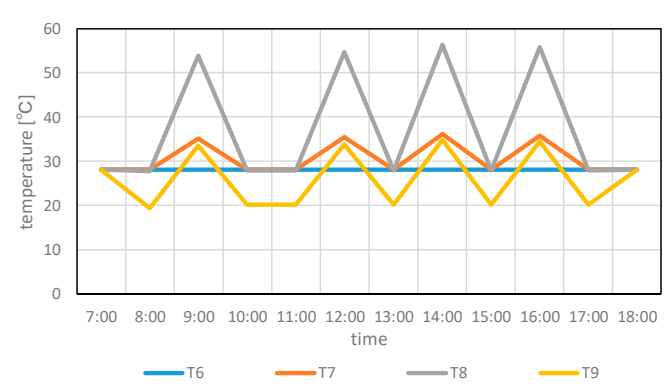

(c) Temperature of the regeneration side

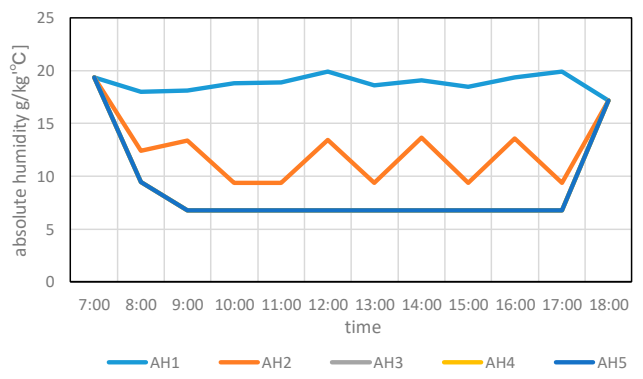

(b) Absolute humidity of the processed side

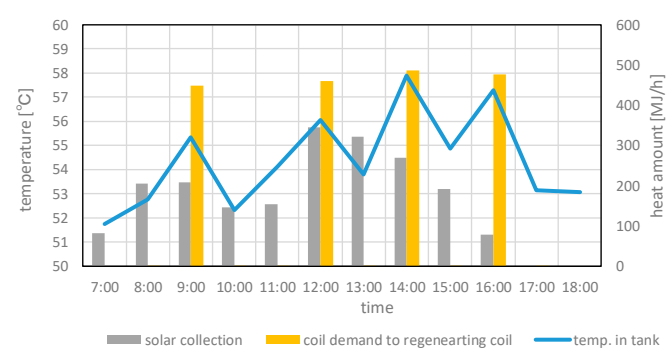

(d) Solar collection, coil demands of the regeneration coil, and temperature in the tank

Figure 7. Diurnal behavior of the flexible control with an evacuated tube type collector.

\subsection{Performance Evaluation}

For evaluation, the performance of the desiccant air handling unit itself is determined with equation (8). For primary energy performance, the desiccant primary energy coefficient of performance (hereafter, $\mathrm{COP})\left(\mathrm{COP}_{\text {des.primary }}\right)$ and the primary-energy base system $\mathrm{COP}\left(\mathrm{COP}_{\text {sys.primary }}\right)$ are defined 
with Equations (9) and (10), respectively. $\mathrm{COP}_{\text {des.primary }}$ provided us with the idea for a comparison of normal cooling, in which chilled water processes the sensible and latent heat load. The COP of the normal cooling is predominated by the COP of the chillers because the total sensible and latent heat loads are assumed to be equal to the chilled water demands. Therefore, if the $\mathrm{COP}_{\text {des.primary }}$ is better than the COP of the chiller in the primary energy base, installing a DAHU is effective for energy conservation.

$$
\begin{gathered}
C O P_{\text {des }}=Q_{\text {pro-s }} /\left(Q_{\text {pre }}+Q_{\text {reg }}+Q_{a f t e r}\right) \\
C O P_{\text {des.primary }}=Q_{\text {pro-s }} /\left(E_{\text {pre }}+E_{r e}+E_{a f t e r}\right) \\
C O P_{\text {sys.primary }}=\left(Q_{c}+Q_{H}\right) /\left(E_{\text {pump }}+E_{H P}\right) .
\end{gathered}
$$

Figure 8 shows the processed sensible and latent heat load for the DAHU and each coil demand. The $\mathrm{COP}_{\text {des }}$ with a flexible control and fixed control has the almost same value, around 0.85 . The total unprocessed latent heat load with a fixed control is $28 \mathrm{GJ}$ for two months, which accounts for $5 \%$ of the required heat load processed by the DAHU. The chilled water coil demand for the DAHU with a flexible control is larger than that with a fixed control because it is necessary to lower the supply air to about $14{ }^{\circ} \mathrm{C}$ when solar thermal energy cannot be utilized.

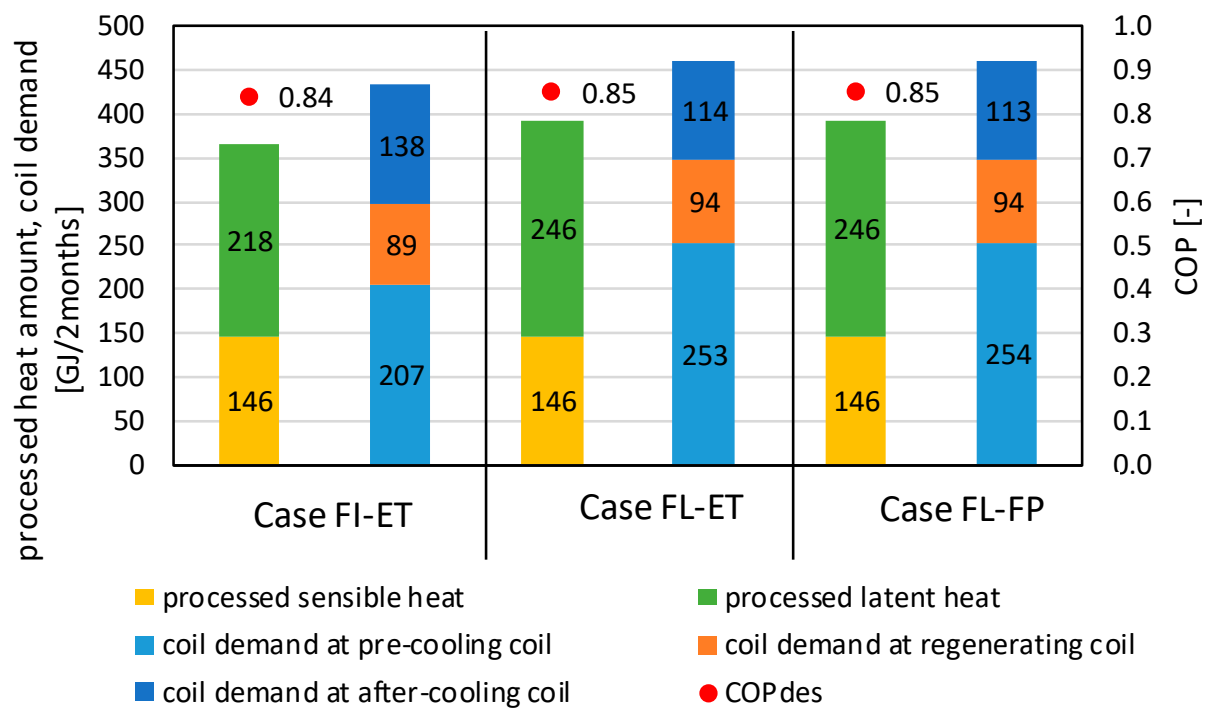

Figure 8. Processed heat, coil demands, and COP of the desiccant air handling unit over two months.

Figure 9 shows the collected heat and solar energy supplied to the regenerating coil for two months. The collected heat is almost $106 \mathrm{GJ}$ for both the fixed and flexible control with an evacuated tube type collector and $112 \mathrm{GJ}$ for the flexible control with a flat type collector. The system with a flexible control can supply more hot water than the fixed control to regenerate the coil. In the system with a fixed control, almost $84 \%$ of the collected heat is supplied to the regenerating coil. In the system with a flexible control and an evacuated tube type collector, approximately $88 \%$ of the collected heat is supplied to the regenerating coil. For a flat plate collector, the ratio of solar thermal utilization $(=83 \%)$ is slightly lower than that of the system with an evacuated tube type collector. This is because the temperature in the tank with a flat type collector is lower than that with an evacuated tube type collector. Even when hot water from the tank is supplied to the regenerating coil, the usable amount of hot water becomes low. However, the COP of solar thermal utilization is highest with the flat type collector among the analyzed cases because the lower temperature in the tank results in higher solar collection efficiency and a larger amount of heat collected hourly. 


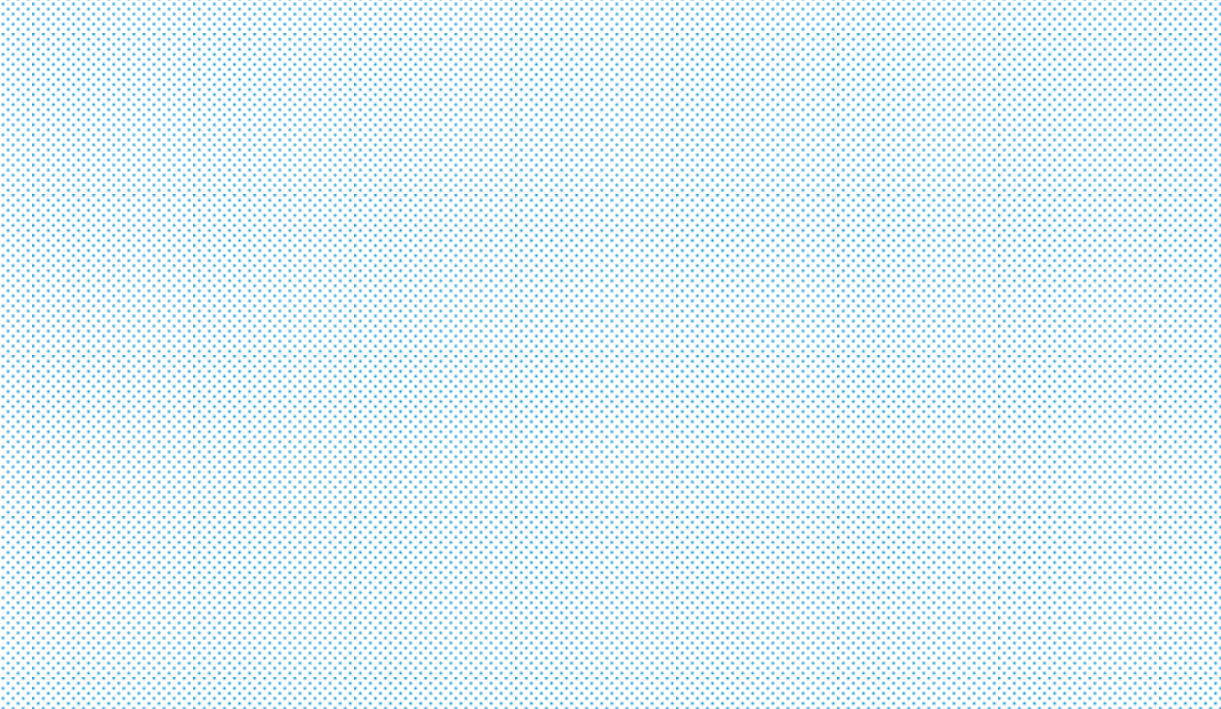

Figure 9. Collected heat and solar energy supplied to the regenerating coil over two months.

As shown in Section 5.1, FI-ET does not process the latent load well because there is no backup heater in case the temperature in the tank is too low to supply the regenerating coil. For the system evaluation, a backup boiler with $80 \%$ primary energy efficiency is considered for FI-ET only.

Figure 10 shows each coil demand for the DAHU and indoor sensible air handling unit, as well as the primary energy consumption.

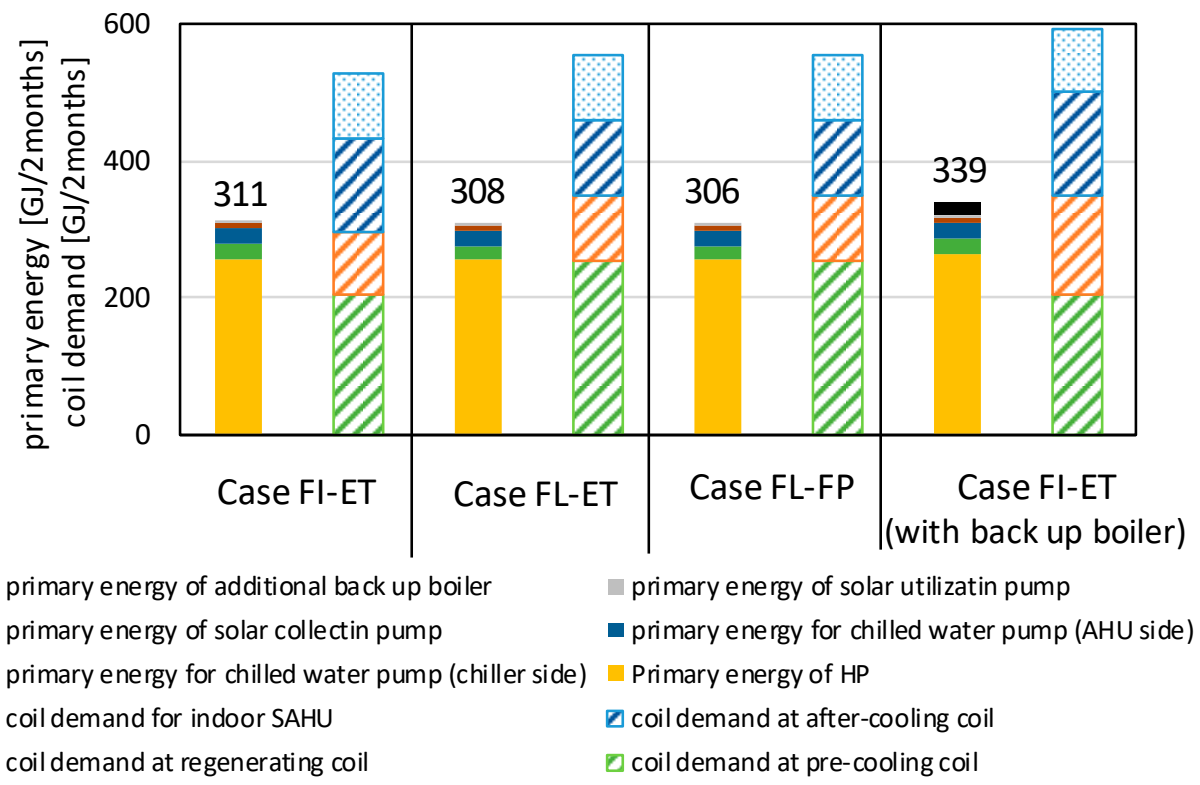

Figure 10. Coil demand for the DAHU and sensible AHU, as well as the primary energy consumption.

In all cases, most of the primary energy consumption is dominated by the heat pump, which accounts for about $80 \%$. For the FI-ET case with a backup boiler, additional hot water for the regenerating coil is necessary, so the regenerating coil demand is larger than that of FI-ET. Furthermore, the primary energy consumption for the boiler is added.

Approximately a $10 \%$ reduction in the primary energy consumption for FL-ET and FL-FP is achieved compared to the FL-ET case with a backup boiler.

Figure 11 shows the $\mathrm{COP}_{\text {des.primary }}$ and $\mathrm{COP}_{\text {sys.primary }}$ for each case. Both COPs for the flexible control are higher than those for the fixed control. Systems with an evacuated tube type collector or a 
flat plate collector can achieve around 1.55 of $\mathrm{COP}_{\text {des.primary }}$ and 1.77 of $\mathrm{COP}$ sys.primary . When installing a backup boiler, both COPs dropped to 1.43 of $\mathrm{COP}_{\text {des.primary }}$ and 1.67 of $\mathrm{COP}_{\text {sys.primary }}$. This drop is caused by installing the backup boiler, for which the primary energy base COP $(=0.8)$ is lower than the solar system COP (= about 9.2).

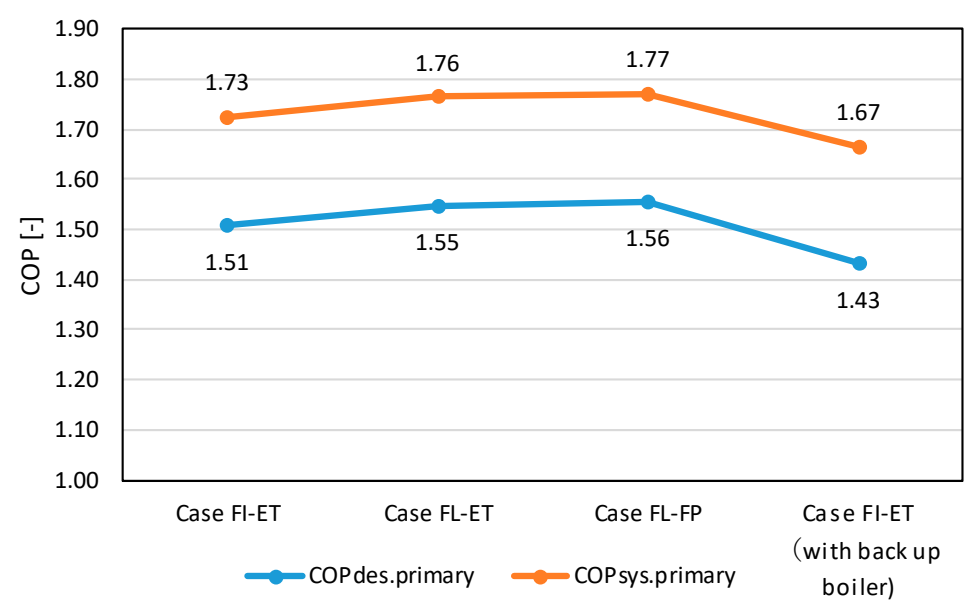

Figure 11. $\mathrm{COP}_{\text {des.primary }}$ and $\mathrm{COP}_{\text {sys.primary }}$ for each case.

\section{Discussion}

As shown in Figures $6 \mathrm{~b}$ and 11, for the fixed control without a backup boiler, there is the possibility that the required latent heat load is not processed properly, which will lead to uncomfortable indoor environments. If there is no stable heat source for the regenerating coil (e.g., a CHP, gas boiler, or electric heater), a flexible control is recommended to be installed for the DAHU system.

Table 4 summarizes the pros and cons of the proposed controls and systems. In terms of primary energy performance in an indoor environment, the system with a flexible control is better than the system with a fixed control. In addition, for the flexible control, the mechanical room will be smaller than that of the fixed control with a backup heat source, resulting in a higher effective area for the office and a larger rentable floor area ratio.

However, additional costs will be necessary for this flexible control since flexible control is advanced.

In hot and humid climates, such as in South East Asia, heating demands and domestic hot water demands in office buildings are low, so backup heaters or boilers for DAHUs are excessive equipment. Instead, using affluent solar thermal energy during the summer for a DAHU can contribute to more sustainable buildings. There is also the possibility to install photovoltaic cells instead of solar thermal collectors, but the efficiency of photovoltaics is still lower than that of solar thermal collectors, and it is not currently possible to compensate for the fluctuation of solar energy. This means that systems with photovoltaic cells need batteries, which will lead to a high installation cost.

As stated in the introduction, global warming is a serious problem. This DAHU system with flexible control will contribute to ameliorating the effects of global warming from the perspective of maintaining indoor environments with smaller energy consumption, as well as allowing the maximum use of renewable energy, such as solar thermal energy, especially in hot and humid climates. 
Table 4. Summary of the pros and cons of the proposed system (based on this study and the authors' opinions).

\begin{tabular}{|c|c|c|c|c|c|}
\hline & Details of Pros and Cons & $\begin{array}{l}\text { Case } \\
\text { FI-ET }\end{array}$ & $\begin{array}{c}\text { Case FI-ET with } \\
\text { a Backup } \\
\text { Boiler/Heater }\end{array}$ & $\begin{array}{c}\text { Case } \\
\text { FL-ET }\end{array}$ & $\begin{array}{c}\text { Case } \\
\text { FL-FP }\end{array}$ \\
\hline \multirow{5}{*}{ Pros } & $\begin{array}{l}\text { Effective use of solar thermal energy } \\
\text { in summer }\end{array}$ & $\sqrt{ }$ & $\sqrt{ }$ & $\sqrt{ }$ & $\sqrt{ }$ \\
\hline & Proper processed latent heat load & & $\sqrt{ }$ & $\sqrt{ }$ & $\sqrt{ }$ \\
\hline & Higher primary energy base $\mathrm{COP}$ & $\sqrt{ }$ & & $\sqrt{ }$ & $\sqrt{ }$ \\
\hline & $\begin{array}{l}\text { Lower initial cost for a flat plate type } \\
\text { collector than an evacuated tube } \\
\text { type collector }\end{array}$ & & & & $\sqrt{ }$ \\
\hline & Smaller space for a mechanical room & $\sqrt{ }$ & & $\sqrt{ }$ & $\sqrt{ }$ \\
\hline Cons & $\begin{array}{l}\text { Higher initial cost for a backup device } \\
\text { Additional costs for advanced control }\end{array}$ & & $\sqrt{ }$ & $\sqrt{ }$ & 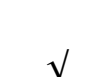 \\
\hline
\end{tabular}

\section{Conclusions}

This study proposed a new "flexible control" for a desiccant air handling unit, which only uses solar energy for its regenerating heat coil. System simulations, including an air conditioning system and a heat source, were conducted to compare flexible control and traditional "fixed control" systems, and the results are provided below.

- The desiccant air handling unit with flexible control can correctly process the required latent heat load, even when solar thermal energy cannot be supplied to the regenerating coil.

- The desiccant air handling unit with a traditional fixed control cannot process the required latent heat load when solar thermal energy is not supplied to the regenerating coil. This unprocessed latent load reaches $28 \mathrm{GJ}$ for July and August. This result proves that a traditional fixed control requires a backup heat source, such as a boiler, electric heater, or combined heat and power.

- Systems with flexible control have better primary energy performance than systems with fixed control. Approximately $10 \%$ of primary energy consumption is achieved under flexible control compared to fixed control with a backup boiler. For the case with an installed evacuated tube type collector, the desiccant COP and primary energy-base system COP of the flexible control reached 1.76 and 1.55 respectively. The desiccant COP and primary energy-base system COP of the fixed control with a backup boiler decreased energy performance by about $5 \%$ (1.67 and 1.43 , respectively).

- For flexible control, there is little difference in the primary energy performance between systems with an evacuated tube type collector and those with a flat type collector. A desiccant air handling unit without a backup heat source will contribute to the wider installation of desiccant air handling units with solar thermal collectors, especially in hot and humid climates.

Author Contributions: Conceptualization, M.U.; Supervision, M.O. and H.T. All authors have read and agree to the published version of the manuscript.

Funding: This work was supported by the JSPS Early-Career Scientists Grant Number 19K15148.

Conflicts of Interest: The authors declare no conflict of interest.

\section{Nomenclature}

A

AV

C

COP area of collector $\left[\mathrm{m}^{2}\right]$

air volume $\left[\mathrm{m}^{3} / \mathrm{h}\right]$

heat capacity [J/kgK]

coefficient of performance 


\begin{tabular}{|c|c|}
\hline dtlm & logarithmic mean temperature difference $[\mathrm{K}]$ \\
\hline $\mathrm{AF}$ & face area of coil $\left[\mathrm{m}^{2}\right]$ \\
\hline $\mathrm{E}$ & primary energy consumption \\
\hline $\mathrm{H}$ & enthalpy $[\mathrm{J} / \mathrm{kg}]$ \\
\hline $\mathrm{J}$ & irradiation $\left[\mathrm{J} / \mathrm{m}^{2}\right]$ \\
\hline K & heat loss factor $\left[\mathrm{J} / \mathrm{Km}^{2}\right]$ \\
\hline KF & heat transfer coefficient [W/ROWm² $\mathrm{K}]$ \\
\hline Q & heat amount $[J]$ \\
\hline qc & heat amount [W] \\
\hline $\mathrm{r}$ & air volume ratio $\left(=\mathrm{AV}_{\mathrm{pro}} / \mathrm{AV}_{\mathrm{re}}\right)[-]$ \\
\hline $\mathrm{RH}$ & relative humidity [\%] \\
\hline ROW & number of coils $[-]$ \\
\hline$S$ & surface area $\left[\mathrm{m}^{2}\right]$ \\
\hline SEC & sensible heat exchange coefficient $[-]$ \\
\hline SHF & sensible heat factor $[-]$ \\
\hline $\mathrm{T}$ & Temperature $\left[{ }^{\circ} \mathrm{C}\right]$ \\
\hline $\mathrm{U}$ & face velocity of DAHU [m/s] \\
\hline uf & face velocity of coil $[\mathrm{m} / \mathrm{s}]$ \\
\hline $\mathrm{V}$ & volume $\left[\mathrm{m}^{3}\right]$ \\
\hline $\mathrm{vw}$ & flow rate of water in coil $[\mathrm{m} / \mathrm{s}]$ \\
\hline W & flow rata $\left[\mathrm{m}^{3} / \mathrm{h}\right]$ \\
\hline WSF & coefficient of the wetted surface \\
\hline$\eta_{\mathrm{RH}}$ & relative humidity efficiency [-] \\
\hline$\eta_{\mathrm{col}}$ & collection efficiency [-] \\
\hline$\rho$ & density $\left[\mathrm{kg} / \mathrm{m}^{3}\right]$ \\
\hline Constant values from the manufacturers & $\mathrm{a} 1 \sim \mathrm{a} 10$ \\
\hline Constant value & $b, d, e, f, g, h, i, j, k, l, m, n, o$ \\
\hline
\end{tabular}

\section{Subscript}

$\begin{array}{ll}\text { after } & \text { after-cooling coil } \\ \text { amb } & \text { ambient air } \\ \text { C } & \text { chilled water } \\ \text { cai } & \text { air state entering coil } \\ \text { cao } & \text { air state leaving coil } \\ \text { cwi } & \text { water state entering coil } \\ \text { cwo } & \text { water state leaving coil } \\ \text { col } & \text { solar thermal collector } \\ \text { col-in } & \text { inlet of solar thermal collector } \\ \text { col-out } & \text { outlet of solar thermal collector } \\ \text { des } & \text { desiccant air handling unit } \\ \text { des.primary } & \text { primary energy base for desiccant air handling unit } \\ \text { H } & \text { hot water } \\ \text { HP } & \text { heat pump } \\ \text { pre } & \text { pre-cooling coil } \\ \text { pro } & \text { process side } \\ \text { pro-s } & \text { processed air } \\ \text { Pump } & \text { pumps for whole system } \\ \text { re } & \text { regeneration side } \\ \text { reg } & \text { regenerating coil } \\ \text { RH } & \text { relative humidity } \\ \text { sup } & \text { supplied to regenerate the coil from the thermal storage tank } \\ \text { sys.primary } & \text { primary energy base for the whole system } \\ & \end{array}$


ts

$\mathrm{W}$

$2,3,8$ solar thermal storage tank

chilled or hot water of coils

number in Figure 3

\section{Appendix A}

Figure A1 shows the relationship between the relative humidity at Num. 2 and the coefficient of the relative humidity in two different office buildings: Building A is in Tokyo, and building B is in Shizuoka (both in Japan). Data for the two buildings were recorded every $1 \mathrm{~min}$. These data were converted to one-hour average data, as shown in Figure A1. The data for building A was collected in July and August 2017, and the data for building B was taken in July and August 2014. According to this relation, we set the coefficient of relative humidity at a constant value of 0.9 because the relative humidity entering the dehumidification wheel on the process side was almost $95 \%$.

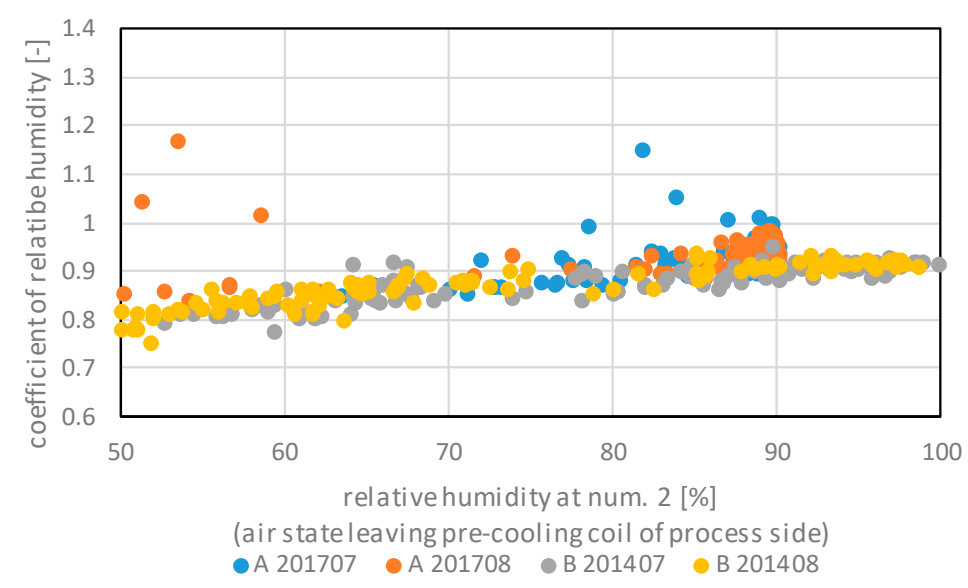

Figure A1. Actual measurement data for the relationship between relative humidity and the coefficient of relative humidity for two different office buildings in Japan.

\section{References}

1. Energy Efficiency and Conservation Division, Agency for Natural Resources and Energy Minsistry of Economy, Trade and Industry. Definition of ZEB and Future Measures Proposed by the ZEB Roadmap Examination Comiittee. 2015. Available online: https://www.enecho.meti.go.jp/category/saving_and_new/ saving/zeb_report/pdf/report_160212_en.pdf (accessed on 25 February 2020).

2. European Commission. Nearly Zero-Energy Buildings. Available online: https://ec.europa.eu/energy/ en/topics/energy-efficiency/energy-performance-of-buildings/nearly-zero-energy-buildings (accessed on 25 February 2020).

3. Office of Energy Efficiency and Renewable Energy, U.S. Department of Energy. Available online: https: //www.energy.gov/eere/buildings/zero-energy-buildings (accessed on 25 February 2020).

4. Ahmed, K.; Yoon, G.; Ukai, M.; Kurnitski, J. How to compare energy performance requirements of Japanese and European office buildings. In Proceedings of the E3S Web of conference 111, Bucharest, Romania, 26-29 May 2019.

5. Tanimoto, M.; Iizuka, S.; Xuan, Y. Numerical study on thermal and wind environments in the Nagoya metropolitan area using WRF (Part14) Future projections of dry island phenomenon and its impact on human thermal comfort. In Summaries of Technical Papers of Annual Meeting; Architectural Institute of Japan: Kobe, Japan, 2014; pp. 931-932. (In Japanese)

6. Ge, T.S.; Dai, Y.J.; Wang, R.Z. Review on solar powered rotary desiccant wheel cooling system. Renew. Sustain. Energy Rev. 2014, 39, 476-497. [CrossRef]

7. Angrisani, G.; Rosella, C.; Saasso, M.; Tariello, F. Dynamic performance assessment of a solar-assisted desiccant-based air handling unit in two Italian cities. Energy Conserv. Manag. 2016, 113, 331-345. [CrossRef]

8. Fong, K.F.; Chow, T.T.; Lee, C.K.; Lin, Z.; Chan, L.S. Advancement of solar desiccant cooling system for building use in subtropical Hong Kong. Energy Build. 2010, 42, 2386-2399. [CrossRef] 
9. Comio, F.; Castillo Gonzalez, J.; Navas-Martos, F.J.; Ruiz de Adana, M. Experimental energy performance assessment of a solar desiccant cooling system in Southern Europe climates. Appl. Therm. Eng. 2020, 165, 114579. [CrossRef]

10. Guidara, Z.; Elleuch, M.; Bacha, H.B. New solid desiccant solar air conditioning unit in Tunisia: Design and simulation study. Appl. Therm. Eng. 2013, 58, 656-663. [CrossRef]

11. Enteria, N.; Yoshino, H.; Takakmi, R.; Yonekura, H.; Satake, A.; Mochida, A. First and second law analyses of the developed solar-desiccant air-conditioning system (SDACS) operation during summer day. Energy Build. 2013, 60, 239-251. [CrossRef]

12. White, S.D.; Goldsworthy, M.; Reece, R.; Spillmann, T.; Gorur, A.; Lee, D.-L. Characterization of desiccant wheels with alternative materials at low regeneration temperatures. Int. J. Refrig. 2011, 34, 1786-1791. [CrossRef]

13. Kato, M.; Umemura, S.; Choi, Y.; Zhou, L.; Horikoshi, T.; Yamagishi, A.; Yamashita, Y.; Amano, K.; Okamura, K. Thermal comfort envelope in an office environment. In Summaries of Technical Papers of Annual Meeting; Architectural Institute of Japan: Niigata, Japan, 1992; pp. 857-858. (In Japanese)

14. "COOL BIZ" Campaign, Ministry of the Environment. Available online: https://www.env.go.jp/en/earth/cc/ framework/5th/04_chpt3.pdf (accessed on 30 January 2020).

15. Micro HASP/TES. Available online: http://www.jabmee.or.jp/hasp/ (accessed on 30 January 2020). (In Japanese)

16. LCEM (Life Cycle Energy Management) Tool. Available online: http://www.mlit.go.jp/gobuild/sesaku_lcem_ lcem.html (accessed on 30 January 2020).

17. Ito, M.; Sugihara, Y.; Murakami, S.; Okumiya, M.; Tokita, S.; Niwa, H.; Tanaka, H.; Watanabe, T.; Yoshinaga, N.; Miura, K.; et al. Development of HVAC system simulation tool for life cycle energy management Part 1: Outline of the developed simulation tool for life cycle energy management, Part 2: Development of component models for HVAC equipment. Proc. Build. Simul. 2007, 1, 178-179. [CrossRef]

18. Japan Exlan Co., Ltd. DESICCANT MATERIAL "Polymer Sorbent". Available online: https://www.exlan.co. jp/en/products/desiccant/ (accessed on 14 February 2020).

19. Inaba, H.; Kida, M.T.; Horibe, A.; Kaneda, M. Sorption Characteristics of Honeycomb Type Sorption Element Composed of Organic Sorbent. Jpn. Soc. Mech. Eng. 2000, 66, 164-171. (In Japanese) [CrossRef]

20. Duffie, J.A.; Beckman, W.A. Solar Engineering of Thermal Processes, 2nd ed.; a Willey-Interscience Publication; John Wiley \& Sons, Inc.: New York, NY, USA, 1991.

21. Weiss, W.; Spörk-Dür, M. Solar Heat Worldwide, 2019 ed.; druck.at Druck- und Handelsgesellschaft mbH: Leobersdorf, Austria, 2019.

(C) 2020 by the authors. Licensee MDPI, Basel, Switzerland. This article is an open access article distributed under the terms and conditions of the Creative Commons Attribution (CC BY) license (http://creativecommons.org/licenses/by/4.0/). 